\title{
Bartholin's abscess: the role of Chlamydia trachomatis
}

\author{
O P Bleker, D J C Smalbraak, M F Schutte
}

\begin{abstract}
Seventy-seven patients with a Bartholin's gland duct disorder were treated by incision and marsupialisation. At operation $18 \%$ were found to have a cyst and $82 \%$ an abscess. $N$ gonorrhoea was isolated from four abscesses and $C$ trachomatis from one. Bacteriological examination of the uterine cervix yielded one further case of $\mathbf{N}$ gonorrhoea and four more of $C$ trachomatis. $\boldsymbol{N}$ gonorrhoea and $C$ trachomatis are of limited aetiologic importance as causes of Bartholin's duct abscess. However, bacteriological examination for STD of the abscess and the cervix is mandatory because of adequate antibiotic treatment of the patients and their contacts.
\end{abstract}

The Bartholin's gland duct may develop a cyst or an abscess from blockage of the vestibular orifice and/or infection. ${ }^{1}$ The infecting organisms may be commensal or sexually transmitted.

Neisseria gonorrhoea could be isolated from the exudate expressed from Bartholin's ducts in $\mathbf{5 2}$ $(28 \%)$ of 183 consecutive cases of gonorrhoea. ${ }^{2}$ However, from 34 abscesses of Bartholin's ducts only four $(12 \%)$ were found to contain $N$ gonorrhoea by a percutaneous aspiration technique. In the majority of cases facultative gram-negative rods, anaerobic, facultative and aerobic members of the vaginal flora were found. ${ }^{3}$

In 1978 Davies reported Chlamydia trachomatis in the Bartholin's ducts of nine out of 30 selected patients. ${ }^{4}$ In 1983 Sweet et al remarked that "the proportion of cases of Bartholinitis that may be regarded as chlamydial is not known". ${ }^{5}$ Only recently was the presence of $C$ trachomatis demonstrated in a Bartholin's gland abscess for the first time. ${ }^{6}$

We studied 63 consecutive cases of Bartholin's abscess with special attention to the possible presence of $N$ gonorrhoea and $C$ trachomatis. Because the uterine cervix is, in a sense, the natural reservoir for those sexual transmitted diseases, bacteriological

Department of Obstetrics and Gynaecology, Onze Lieve Vrouwe Gasthuis, Amsterdam, The Netherlands

O P Bleker, D J C Smalbraak, M F Schutte examination was performed of the Bartholin's abscess and also of the uterine cervix.

\section{Patients and methods}

From 1984 to 1989,77 patients with Bartholin's gland disorder were treated by incision and marsupialisation. ${ }^{7}$ The mean age was $32 \cdot 2$ years (range: 19-65). The pre-operative clinical diagnosis was a cyst in 21 cases and an abscess in 56. At operation seven patients with Bartholin's cyst showed a purulent content, so the definitive diagnosis was a cyst in 14 cases $(18 \%)$ and an abscess in $63(82 \%)$. In 74 cases bacteriological examination was performed of the Bartholin's gland duct and in 67 patients additional bacteriological examination of the uterine cervix was performed at the time of operation or within one week afterwards. Material was collected by a Transwab (Amies Transportmedium) for bacteriological cultures and a STD-EZE for transport of material for detection of $C$ trachomatis with an ELISA-technique (Abbott), always confirmed by a fluorescent antibody test. ${ }^{8}$ No patient received antibiotics prior to the bacteriological examinations.

\section{Results}

The results of the bacteriological examinations of the Bartholin's duct and the uterine cervix in 77 patients are given in table 1.

In all 14 patients with the definite diagnosis of cyst no bacteriological abnormalities were found. In 63 patients with an abscess about half showed no bacteriological abnormality and about half revealed on culture more or less pathogenic bacteria, as given in table 2. In only one case was Mycoplasma hominis found in the cervix but not in the abscess.

Table 1 shows that the results of bacteriological

Table 1 Bacteriology of Bartholin's gland duct and of the uterine cervix in 77 patients with a cyst or an abscess

\begin{tabular}{lcc}
\hline & $\begin{array}{l}\text { Bartholin's } \\
\text { gland duct } \\
(N)\end{array}$ & $\begin{array}{l}\text { Uterine } \\
\text { cervix } \\
(N)\end{array}$ \\
\hline N gonorrhoea & 4 & 3 \\
C trachomatis & 1 & 4 \\
Other (see table 2) & 26 & 14 \\
None* & 43 & 46 \\
Unknown & 3 & 10 \\
\hline
\end{tabular}

«In all 14 Bartholin's cyst patients no pathogens were found in either duct and cervix. 
Table 2 Non-STD pathogens in 63 Bartholin's abscess patients

\begin{tabular}{lcc}
\hline & $\begin{array}{l}\text { Bartholin's } \\
\text { abscess } \\
(N)\end{array}$ & $\begin{array}{l}\text { Uterine } \\
\text { cervix } \\
(N)\end{array}$ \\
\hline Streptococcus & 10 & 6 \\
Staphylococcus & 1 & 1 \\
Escherichia coli & 6 & 2 \\
Gardnerella vaginalis & 3 & 2 \\
Proteus & 1 & 2 \\
Anaerobic bacteria & 5 & 1 \\
Mycoplasma hominis & - & 14 \\
Total & 26 & \\
\hline
\end{tabular}

Table $3 N$ gonorrhoea and C trachomatis in 63 cases of Bartholin's abscess

\begin{tabular}{lll}
\hline Bartholin's abscess & Uterine cervix & $(N)$ \\
\hline NG & NG & 2 \\
NG & - & 1 \\
Unknown & 1 \\
CT & NG & 1 \\
Total & CT & 1 \\
& & 4 \\
\hline
\end{tabular}

NG $=$ Neisseria gonorrhoea

$\mathrm{CT}=$ Chlamydia trachomatis.

examination was unknown from Bartholin's duct in 3 cases, and from the cervix in 10 cases.

The results with respect to $N$ gonorrhoea and $C$ trachomatis are given in table 3. $N$ gonorrhoea was isolated from four abscesses and $C$ trachomatis from one. Bacteriological examination of the uterine cervix yielded one further case of $N$ gonorrhoea and four more of $C$ trachomatis (table 3 ).

\section{Discussion}

Nowadays the standard surgical treatment of a Bartholin's duct swelling, whether cyst or abscess, is incision and marsupialisation. ${ }^{17}$ Adjuvant antibiotic treatment is not recommended.

We found no pathogenic bacteria in 29 of 63 Bartholin's abscesses $(46 \%)$ and simple pathogenic bacteria is another 26 cases (41\%) (tables 1 and 2). In agreement with Lee $e t a \mathcal{l}^{\beta}$ in the majority of cases, Bartholin's abscesses are found to be. sterile or to contain non-STD bacteria. However, table 3 shows that in ten (or 16\%) of the Bartholin's abscess cases a STD was found: five cases of $N$ gonorrhoea $(8 \%)$ and five of $C$ trachomatis ( $8 \%$ ).

With respect to $N$ gonorrhoea our results confirm the limited aetiologic role in Bartholinitis ${ }^{3}$ : in only four out of 63 abscesses was $N$ gonorrhoea found ( $6 \%$ ) and in two of those cases simultaneously in the uterine cervix (table 3 ). The fifth case of $N$ gonorrhoea was only found in the cervix (table 3 ).
With respect to $C$ trachomatis the results of our study are different. In only one case $(2 \%)$ was $C$ trachomatis found in a Bartholin's abscess.

In four other cases $C$ trachomatis was found in the uterine cervix alone and not in Bartholin's abscess (table 3). An explanation could be that it is difficult to detect $C$ trachomatis in abscess material. Another explanation could be that an abscess is a rather late stage of the infection and may not contain the primary aetiology infective agent. The incidence of cervical $C$ trachomatis in our Bartholin's abscess patients $(4 / 63=6 \%)$ is very similar to the incidence found in our department among patients without complaints (who are pregnant or candidates for IUD-use): $7-8 \% .{ }^{9}$ This limits the possible aetiological role of $C$ trachomatis in Bartholin's abscess. Nevertheless in Bartholin's abscess patients bacteriological examination for such STD agents as $N$ gonorrhoea and $C$ trachomatis of both the abscess and the cervix is indicated. In $16 \%$ of cases an STD was found, which indicates the need for adjuvant antibiotic treatment of the patients and their sexual partners.

\section{Conclusions:}

1. One third of Bartholin's gland cyst are abscesses, which becomes obvious at surgery.

2. The aetiologic role of $C$ trachomatis in Bartholin's abscess is rather limited.

3. Bacteriological examination of both Bartholin's abscess and the uterine cervix doubles the finding of STD.

Address for reprints: O P Bleker, $\mathrm{MD}$. PhD, Onze Lieve Vrouwe Gasthuis, le Oosterparkstraat 179, 1091 HA AMSTERDAM, The Netherlands

1 Word B. Office Treatment of Cyst and Abscess of Bartholin's Gland Duct. South Med J 1968;61:514-8.

2 Rees E. Gonococcal Bartholinitis. Br J Venereal Dis 1967; 43:150-6.

3 Lee YH, Rankin JS, Alpert S, Daly AK, McCormack WM. Microbiological investigation of Bartholin's gland abscesses and cysts. Am J Obstet Gynecol 1977;129:150-3.

4 Davies JA, Rees E, Hobson D, Karrayiannis P. Isolation of Chlamydia Trachomatis from Bartholin's Ducts. $\mathrm{Br} J$ Venereal Dis 1987;54:409-13.

5 Sweet RL, Schachter J, Landers DV, et al. Chlamydial infections in obstetrics and gynecology. Clin Obstet Gynecl 1983; 26:1:143-64.

6 Saul HM, Grossman MB. The role of Chlamydia Trachomatis in Bartholin's gland abscess. Am J Obstet Gynecol 1988;158: 576-7.

7 Jacobson P. Marsupialisation of vulvovaginal (Bartholin) cysts. Am J Obstet Gynecol 1960;79:73-8.

8 Schoot JM van der, Dirks-Go SIS, Bleker OP, Lammes FB. The problem of the golden standard in non ideal circumstances. European Society for Medical Decision Making, First Congress, Leyden, The Netherlands, 1986:70.

9 Bleker OP, Schoot J Th M van der, Dirks-Go SiS. Cervicitis en Salpingitis. Tijdschrift voor Sexueel Overdraagbare Aandoeningen 1987;3:4:4-9. 